(c) American Dairy Science Association, 2003.

\title{
Free Oil and Rheology of Cheddar Cheese Containing Fat Globules Stabilized with Different Proteins
}

\author{
D. W. Everett and N. F. Olson \\ Department of Food Science, University of Wisconsin, Madison 53706
}

\section{ABSTRACT}

Cheddar cheese was manufactured from recombined milk containing fat globules coated with $\alpha_{\mathrm{s} 1}$-CN (casein), $\alpha_{\mathrm{s} 2}-\mathrm{CN}, \beta$-CN, $\kappa$-CN, $\alpha$-lactalbumin, or $\beta$-lactoglobulin. The effect of the coating on fat globule structure, free oil formation, and cheese rheology was investigated to determine if globule coating affected the physical structure of cheese. Fat globule size and shape were determined in cheese using confocal laser scanning microscopy, and the rheological properties measured by uniaxial compression after maturation for 35 and $70 \mathrm{~d}$. Fat globules were elongated and clustered in the control cheese coated with native membrane material and in cheese where the globules were coated with $\alpha_{\mathrm{s} 2^{-}} \mathrm{CN}$, but were more circular and distinct than all others. Cheese containing globules coated with $\alpha_{\mathrm{s} 2}-\mathrm{CN}$ fractured at a lower strain and with a lower stress than other experimental cheeses. Free oil decreased in cheese as the stress at fracture of the cheese protein matrix increased. Strain at fracture increased as $\mathrm{pH}$ increased from 4.7 to 5.3. There was no correlation between free oil and fat globule circularity. Cheddar cheese aroma was not evident in experimental cheeses. (Key words: free oil, cheese, fat globule, rheology)

Abbreviation key: CLSM = confocal laser scanning microscopy, $\mathbf{S R}=$ springiness ratio, $\mathbf{T}=$ surface tension .

\section{INTRODUCTION}

Fat exists in an emulsified state in milk, however the state in cheese is not conclusively known. Fat may exist in an emulsified form in cheese or as pools of fat filling the voids in the cheese protein matrix. The state of the fat may influence the textural properties of the cheese through such factors as the size of the globule or pool of fat, or by the nature of the surface coating if interaction between the globule surface and the surrounding pro-

Received March 21, 2002.

Accepted August 10, 2002.

Corresponding author: David W. Everett; e-mail: d.everett@ otago.ac.nz. Current address: Dept. of Food Science, University of Otago, New Zealand. tein matrix takes place. The shape of the globules has been observed to change during cheesemaking (Kaláb and Emmons, 1978). During aging of cheese, emulsified fat may become disrupted and form a pool of fat by chemical or enzymatic degradation of the globule stabilizing membrane, or by physical pressures imposed upon the globule by continual rearrangements of the protein matrix (Kimber et al., 1974).

Homogenization of milk prior to cheesemaking is a simple method to alter the surface-active species adsorbed at the interface (Law et al., 1973). Fat globules that are homogenized in milk are partially coated with casein micelles that participate via cross-linking in the casein protein network of the cheese (van Vliet and Dentener-Kikkert, 1982). The fat globule size is reduced in the process and the increased oil-water interfacial area is stabilized by adsorption of milk components, most likely $\beta$-CN, the most surface-active of the major milk proteins (Dickinson et al., 1990). The effect may contribute to a stiffening of the protein network by allowing the protein adsorbed onto the surface of the small fat globules to interact with the surrounding casein matrix.

Increasing the homogenization pressure on milk before manufacture of reduced-fat Cheddar cheese results in a higher moisture content, and decreased firmness, cohesiveness and elasticity of the cheese (Emmons et al., 1980). The opposite effect is observed when homogenizing milk prior to the manufacture of a fresh cheese (Korolczuk and Mahaut, 1992). Renneting of homogenized milk causes the aggregation of casein micelles to proceed at a slower pace, the curd network to become finer and the rate of whey loss to decrease, as compared to renneted non-homogenized milk (van Vliet and Dentener-Kikkert, 1982). The effect of emulsifying oil with low molecular weight surfactants, including lecithin, has been examined for model processed cheese (Lee et al., 1996). We are unaware of any similar work on renneted matured cheese.

In the present study, milk fat is emulsified with different milk proteins $\left(\alpha_{\mathrm{s} 1}-\mathrm{CN}, \alpha_{\mathrm{s} 2^{-}} \mathrm{CN}, \beta-\mathrm{CN}, \kappa\right.$-CN, $\alpha$ LA or $\beta$-LG), mixed with skim milk, and manufactured into Cheddar cheese. Cheese manufactured with globules coated with native membrane material was also 
examined as a control. The effect of globule coating on fat globule structure, rheological properties, and free oil formation in the cheese was investigated after 35 and $70 \mathrm{~d}$ maturation.

\section{MATERIALS AND METHODS}

\section{Preparation of Emulsions}

Caseins, $\left(\alpha_{\mathrm{s} 1^{-}}, \alpha_{\mathrm{s} 2^{-}}, \beta\right.$ - and $\kappa$-CN), whey proteins $(\alpha-$ $\mathrm{LA}$ and $\beta-\mathrm{LG}$ ), and anhydrous milk fat were obtained, and purified as previously described (Everett and Olson, 2000). A standard procedure was used to prepare protein samples (Shalabi and Fox, 1987) for urea-PAGE (Andrews, 1983). The gels were dried and analyzed for band density to assess the purity of proteins.

Emulsions (30\% milk fat) were prepared containing fat globules coated with either $\alpha_{\mathrm{s} 1}-\mathrm{CN}, \alpha_{\mathrm{s} 2}-\mathrm{CN}, \beta-\mathrm{CN}$, $\kappa$-CN, $\alpha$-LA, or $\beta$-LG in a $0.1 M \mathrm{pH} 7$ imidazole buffer (Everett and Olson, 2000). Emulsions were initially formed with differing amounts of protein, set in a polyacrylamide gel, and the diameter of homogenized fat globules measured by confocal laser scanning microscopy (CLSM). From this data, the amount of protein used to emulsify milk fat for cheesemaking experiments was calculated at $6 \mathrm{~g}$ per $720 \mathrm{~g}$ of fat to yield an average globule diameter of $3 \mu \mathrm{m}$, assuming that the ratio of adsorbed to unadsorbed protein remained constant as the concentration changed. Control emulsions were made where natural cream (30\% milk fat) was separated from milk, then blended and homogenized (Everett and Olson, 2000). Imidazole was added to the control cream in solid form to a final concentration of $0.1 \mathrm{M}$. The fat globule size in the emulsions was confirmed in all cases by CLSM.

\section{Cheese Manufacture}

A blend of three strains of Lactococcus lactis ssp. cremoris (DVS 970 frozen concentrate, Chr. Hansen's Laboratory, Inc., Milwaukee, WI) was used in the manufacture of full-fat Cheddar cheese. An $8 \%$ solution of Phase $4^{\circledR}$ cheese starter culture medium (RhônePoulenc, Inc., Madison, WI) containing whey, yeast extract, and phosphate-citrate buffer was heated in a 5 $\mathrm{L}$ glass flask at $85^{\circ} \mathrm{C}$ for $40 \mathrm{~min}$, inoculated with $0.45 \%$ starter culture, and incubated for 5 to $10 \mathrm{~h}$ at $27^{\circ} \mathrm{C}$ until $\mathrm{pH} 5.1$ was reached. Milk for cheese manufacturing was inoculated with $0.7 \%$ of the starter culture medium. All utensils were sanitized with a $200 \mathrm{mg} / \mathrm{kg}$ solution of sodium hypochlorite before use.

Milk was obtained from the University of Wisconsin dairy farm (Arlington, WI), skimmed and pasteurized at $74^{\circ} \mathrm{C}$ for $15 \mathrm{~s}$. Prepared emulsions or homogenized natural cream $(2.27 \mathrm{~L})$ was added to skim milk (17.73
L) to yield a final fat content of $3.4 \%$ and manufactured into full-fat Cheddar cheese in $20 \mathrm{~L}$ stainless steel vats. The prepared emulsions or cream were mixed thoroughly into the skim milk, and no further stirring took place during the milk ripening step to minimize shearinduced desorption of fat globule material from the membrane layer of the globules. Double strength fermentation-derived recombinant chymosin (EC 3.4.23.4, $0.016 \%$, Pfizer, Inc., Milwaukee, WI) was used to coagulate the milk. Average coagulation time was $37 \pm 10$ min. Curds and whey were cooked to $40^{\circ} \mathrm{C}$ and drained at $\mathrm{pH}$ 6.20. The slabs of cheese curd were cheddared, and milled at $\mathrm{pH}$ 5.50. The finished pressed cheese blocks were sealed in plastic barrier bags under vacuum and matured at $8^{\circ} \mathrm{C}$.

Six experimental cheeses were manufactured, corresponding to the six protein coatings used to prepare the emulsions, three on one day using the same batch of skim milk, and three on another day using a second batch of milk. One control cheese was made on each cheesemaking day, making two control cheese in total.

Composition of cheese. Cheese $\mathrm{pH}$ was measured by the gold electrode quinhydrone method, moisture by a vacuum oven technique, and fat by the Babcock test (Richardson, 1985). Sodium chloride was determined coulometrically (Johnson and Olson, 1985) using a model 926 chloride analyzer (Corning Glass Works, Medfield, MA). All measurements were made in triplicate.

Free oil. The test for free oil in Cheddar cheese was modified from one developed for Mozzarella cheese (Kindstedt and Rippe, 1990). Methanol was added to minimize the formation of protein flocs in the measuring tube that would obscure the interface between the aqueous phase and the fat column. The time that the cheese was in contact with boiling water was increased from four to 12 minutes; this was found to be necessary as Cheddar cheese yielded only small volumes of oil after boiling for four minutes. Free oil was expressed as a weight percentage of total fat and measurements were made in triplicate.

\section{Confocal Laser Scanning Microscopy}

An MRC-600 confocal laser scanning microscope (BioRad Microscience Ltd., Hertfordshire, United Kingdom) with $60 \times$ Nikon lens was employed to measure the size of fat globules in emulsions prior to cheesemaking, and to examine the fat globule structure of cheese after 35 and $70 \mathrm{~d}$ of maturation (Brakenhoff et al., 1988; Blonk and van Aalst, 1993; Inoue, 1995). A Kalman software filter was used to reduce noise in each two-dimensional image $(768 \times 512$ pixels per image, or $30.9 \times 20.6 \mu \mathrm{m})$ 
by taking three successive images and averaging the results.

Correction factor in two-dimensional confocal microscopy. A correction was made to the size of particles in each two-dimensional image to account for possibility that a planar sectional image may be observed at some distance from the equatorial plane of a sphere. This would cause the apparent radius to be smaller than the true radius.

A sphere in $(x, y, z)$ coordinates is given by the equation

$$
x^{2}+y^{2}+z^{2}=r^{2}
$$

where $\mathrm{r}=$ true radius of the sphere. Define $\mathrm{a}=$ the distance from the center of the sphere to the center of the planar circle observed in the confocal microscope. At this point, $\mathrm{z}=\mathrm{a}$, and the equation of the circle seen in the microscope is given by

$$
x^{2}+y^{2}=r^{2}-a^{2}
$$

giving an apparent radius of

$$
r_{a p p}=\sqrt{r^{2}-a^{2}}
$$

Therefore the area (A) of the observed circle is given by

$$
A=\pi\left(r^{2}-a^{2}\right)
$$

At $r=a$, the plane of observation under the microscope just touches either the top or the bottom of a sphere. If this occurs, the globule will not be seen under the microscope. This will give an apparent radius of $r_{\text {app }}=0$.

If a large number of sections are taken of a particle and the measured radii averaged, the value will approach

$$
\frac{\pi}{r} \int_{a=r}^{a=0}\left(r^{2}-a^{2}\right) \cdot d a=\frac{\pi}{r}\left[r^{2}-\frac{a^{3}}{3}\right]_{a=r}^{a=0}=\frac{\pi}{3} \mathbf{r}^{2}
$$

which equals one third of the area at the equatorial circumference. The apparent radius therefore approaches $1 / \sqrt{ } 3$ of the value of the true radius.

Cheese. Samples were prepared by cutting three 1$\mathrm{mm}$ thick cheese cores, with $2 \mathrm{~mm}$ diameter, at $8^{\circ} \mathrm{C}$. The aqueous protein phase of the cheese was stained by immersion for $2 \mathrm{~min}$ in a fluorescent $0.1 \%$ aqueous solution of rhodamine $\mathrm{B}$ containing $4.6 \% \mathrm{NaCl}$ and saturated with $\mathrm{Ca}_{3}\left(\mathrm{PO}_{4}\right)_{2}$, with subsequent observation in the confocal microscope using a $568 \mathrm{~nm}$ filter (Yiu, 1985). The dye solution contained a mineral environ- ment similar to cheese, designed to minimize distortions of the protein structure that might affect the shape of the fat globules. The staining solution was at $\mathrm{pH}$ 5.6, however no further $\mathrm{pH}$ adjustment of the dye was deemed necessary because of the high buffering capacity of Cheddar cheese.

In a separate experiment, Nile Red fluorescent lipid stain was directly applied in solid form to cheese previously stained with rhodamine $B$. The cheese was observed under CLSM using a dual-beam to observe both the lipid and aqueous phase fluorescent areas. A 647 $\mathrm{nm}$ filter was used to view the fluorescent lipid phase.

Image analysis. Confocal images were analyzed by a computerized image analysis software package, NIHImage (Natl. Institutes of Health, Washington, DC), to determine fat globule area in each plane of measurement (A) and length of the globule perimeter (L). Globule radius ( $R$ ), assuming a circular shape, was calculated from the expression

$$
\mathrm{R}=\sqrt{\mathrm{A} / \pi}
$$

Circularity (C) was calculated from the expression

$$
\mathrm{C}=\frac{2 \pi \sqrt{\mathrm{A} / \pi}}{\mathrm{L}}
$$

where a circularity of one indicates a sphere, and less than one an increasing degree of distortion.

Particles smaller than a certain size will yield an exaggerated average circularity (greater than one in some cases) due to the pixelated nature of the images, so only particles that are greater than a designated cutoff size of 12 pixels were included, equivalent to $0.4 \mu \mathrm{m}$ radius or twice the minimum resolution for the $60 \times$ CLSM lens. The distribution of fat globule circularity was normalized by taking the square of circularity, allowing an ANOVA analysis of this mathematically transformed variable.

\section{Cheese Rheology}

The texture of Cheddar cheese was quantified by uniaxial compression of cheese cores using a model 1130 Instron Universal Testing Machine (Instron Corporation, Canton, MA) at $21 \pm 1^{\circ} \mathrm{C}$. A $22.7 \mathrm{~kg}$ load cell was used for $20 \%$ compression of the cheese cores, and a $453.6 \mathrm{~kg}$ load cell for fracture of the cheese. The rate of compression was set at $51 \mathrm{~mm}$ per min.

Ten cheese cores ( $2 \mathrm{~cm}$ diameter $\times 2 \mathrm{~cm}$ height) were cut from the cheese block and lubricated on both ends with light mineral oil to reduce the effects of friction between the plate and the cheese surface during com- 
pression (Ak and Gunasekaran, 1992). The cheese core was subjected to a double-bite $20 \%$ compression and the ratio of the area under the second compression to the area under the first compression was calculated as springiness ratio (SR). Ten additional cheese core samples were taken from the same block, compressed to $80 \%$, and stress and strain at the point of fracture measured. True compressive stress and Hencky strain were used in this analysis (Peleg, 1984). Results were calculated from the average of the 10 cores from each block of cheese for both compression and fracture analysis.

\section{RESULTS}

The whey was clear after cutting the curd during cheesemaking in all cases. Cheese with $\alpha_{\mathrm{s} 2}$-CN-coated globules was oily, mealy, crumbly and mottled in appearance. All experimental cheeses made from recombined milk lacked a characteristic Cheddar aroma, whereas the control cheeses had the expected aroma. It was initially thought that the process of high-speed blending prior to homogenization incorporated air into the emulsion, reducing the expected aroma, however blending natural cream prior to cheesemaking did not produce a cheese with less Cheddar cheese aroma.

Compositional analysis. The moisture in non-fat substance for the experimentally coated globule cheeses averaged $56.4 \pm 0.4 \%$, lower $(P=0.006)$ than that of the corresponding control cheeses $(59.9 \pm 1.0 \%)$. The fat in dry matter for the experimentally coated globule cheeses was $54.8 \pm 1.1 \%$, not significantly different $(P$ $=0.941)$ from the control cheeses $(54.7 \pm 0.6 \%)$. Salt content of the experimentally coated globule cheeses was $1.91 \pm 0.13 \%$, and for the control cheeses $1.89 \pm$ $0.26 \%$, and were not significantly different $(P=0.926)$.

Fat globule size and shape. Cheese stained with both a water soluble dye (rhodamine B) and a lipid soluble dye (Nile Red) showed that the oil- and watersoluble fluorescent areas did not overlap. As there were no significant areas in the cheese that did not fluoresce in either of the micrographs, the total volume of gas holes in cheese was concluded to be small or non-existent.

True fat globule radius, circularity, and the number of fat globules measured in each image are recorded in Table 1 for cheese matured 35 and $70 \mathrm{~d}$. The amount of protein added $(6 \mathrm{~g})$ resulted in fat globules within the intended 2 to $4 \mu \mathrm{m}$ radius range (Table 1 ). The larger globules were less circular, and thus more irregularly shaped, for cheese containing globules coated with $\alpha_{\mathrm{s} 2}$-CN (Figure 1). This was also the case for all cheeses examined by CLSM. Circularity of fat globules did not significantly change over this time period.
A CLSM micrograph of a control cheese after $70 \mathrm{~d}$ maturation shows larger, more irregular globules (Figure 2) compared to the micrograph showing cheese containing fat globules coated with $\alpha$-LA at the same age (Figure 3). A partial alignment of fat globules is evident in Figure 2, which may occur if native milk fat globules undergo coalescence and are aligned after cheese pressing. In contrast, the globules coated with $\alpha$-LA (Figure 3) do not exhibit this alignment, and retain their globular shape. Fat globules appear to exist in two formssmall circular globules (2 to $4 \mu \mathrm{m}$ in size) and larger more irregular clusters of particles (10 to $20 \mu \mathrm{m}$ in size) in cheeses made with milk fat emulsified with $\alpha_{\mathrm{s} 2}$-CN (Figure 4).

Free oil. Free oil decreased over the $35 \mathrm{~d}$ maturation period for whey protein-coated globule cheeses ( $\alpha$-LA and $\beta$-LG), whereas it increased or remained unchanged for the casein-coated cheeses (Table 1). The control cheeses either were unchanged or showed an increase in free oil over the $35 \mathrm{~d}$ period. Free oil decreased as the stress at fracture increased (Figure 5). Data from $35 \mathrm{~d}$ and $70 \mathrm{~d}$ of ripening followed a similar trend.

Cheese rheology. The decrease in firmness from 35 to $70 \mathrm{~d}$, quantified by stress at fracture (Table 2), probably resulted from proteolysis of $\alpha_{\mathrm{s} 1}$-CN during cheese maturation. This protein provides the primary structure of the cheese protein matrix, so would cause a softening of the structure when undergoing proteolysis.

Fracture of the cheese occurred at a point between $20 \%$ and $80 \%$ compression in all cases measured. Cheese cores fractured at a point where force reached the first peak (or point of inflection) during compression. In most cases SR and stress at fracture decreased or remained constant from 35 to $70 \mathrm{~d}$ of maturation (Table 2). Cheese containing $\alpha_{\mathrm{s} 2}-\mathrm{CN}$-coated globules fractured at a lower stress and a smaller strain, and was also less elastic as quantified by SR, compared to other cheeses. The control cheeses mostly showed a smaller stress at fracture compared to the experimental cheeses (with the exception of the $\alpha_{\mathrm{s} 2}$-CN cheese).

Strain at fracture increased with $\mathrm{pH}$ in the range 4.95 to 5.25 , showing a similar trend regardless of age or fat globule coating (Figure 6). It is noteworthy that cheeses containing fat globules coated with $\alpha_{\mathrm{s} 2}$-CN fractured at a lower strain than would be expected from the trend. The uniqueness of the $\alpha_{\mathrm{s} 2}-\mathrm{CN}$ coating is also seen where strain at fracture is less than for cheese containing fat globules coated with other experimental coatings (Figure 7).

\section{DISCUSSION}

\section{Fat Globule Size and Shape}

Researchers have questioned whether the "black holes" in cheese images are actually fat globules, or 
Table 1. Free oil, fat globule radius, and circularity in cheese after 35 and $70 \mathrm{~d}$ maturation at $8^{\circ} \mathrm{C}$. Data obtained from image analysis of confocal laser scanning micrographs. ${ }^{1}$

\begin{tabular}{|c|c|c|c|c|c|c|c|c|c|c|c|c|}
\hline \multicolumn{5}{|c|}{$\mathrm{FO}^{2}(\%)$} & \multicolumn{2}{|c|}{$\operatorname{Radius}^{3}(\mu \mathrm{m})$} & \multicolumn{4}{|c|}{ Circularity } & & \\
\hline \multirow{2}{*}{$\begin{array}{l}\text { Coating } \\
\text { material }\end{array}$} & \multicolumn{2}{|c|}{$35 \mathrm{~d}$} & \multicolumn{2}{|c|}{$70 \mathrm{~d}$} & \multirow{2}{*}{$\frac{35 \mathrm{~d}}{\text { Mean }}$} & \multirow{2}{*}{$\frac{70 \mathrm{~d}}{\text { Mean }}$} & \multicolumn{2}{|c|}{$35 \mathrm{~d}$} & \multicolumn{2}{|c|}{$70 \mathrm{~d}$} & \multicolumn{2}{|c|}{$\mathrm{n}^{4}$} \\
\hline & Mean & $\mathrm{SD}$ & Mean & $\mathrm{SD}$ & & & Mean & SD & Mean & SD & $35 \mathrm{~d}$ & $70 \mathrm{~d}$ \\
\hline$\alpha$-LA & 35.2 & 1.1 & 28.3 & 1.0 & 2.19 & 2.00 & 0.89 & 0.10 & 0.91 & 0.09 & 497 & 922 \\
\hline$\beta-\mathrm{LG}$ & 37.6 & 0.5 & 30.00 & 0.16 & 3.27 & 2.82 & 0.85 & 0.11 & 0.89 & 0.10 & 173 & 372 \\
\hline$\alpha_{\mathrm{s} 1}-\mathrm{CN}$ & 11.5 & 1.0 & 12.7 & 0.8 & 2.57 & 2.41 & 0.89 & 0.09 & 0.90 & 0.10 & 307 & 568 \\
\hline$\alpha_{\mathrm{s} 2}-\mathrm{CN}$ & 37.9 & 1.7 & 55.3 & 1.1 & 2.95 & 3.02 & 0.86 & 0.11 & 0.86 & 0.12 & 160 & 277 \\
\hline$\beta$-CN & 35.4 & 0.4 & 38.5 & 0.9 & 3.05 & 3.13 & 0.85 & 0.11 & 0.85 & 0.13 & 204 & 362 \\
\hline$\kappa-\mathrm{CN}$ & 40.3 & 1.2 & 42.0 & 0.8 & 2.31 & 2.50 & 0.88 & 0.10 & 0.90 & 0.11 & 371 & 784 \\
\hline Control 1 & 41.1 & 0.3 & 42.4 & 0.8 & 4.10 & 2.57 & 0.89 & 0.09 & 0.89 & 0.11 & 62 & 327 \\
\hline Control 2 & 44.6 & 0.6 & 50.6 & 1.6 & 2.49 & 2.99 & 0.85 & 0.12 & 0.86 & 0.12 & 215 & 281 \\
\hline
\end{tabular}

\footnotetext{
${ }^{1}$ Two independent control cheeses analyzed. Only particles $>12$ pixels in area included.

${ }^{2}$ Free oil as a percentage of total cheese weight $(\mathrm{n}=10)$.

${ }^{3}$ Radius corrected by multiplying by a factor of $\sqrt{3}$ as described in text. Results expressed as a mean as the data distributions were heavily skewed.

${ }^{4}$ Number of particles measured.
}

perhaps simply air pockets within the cheese. In cheese stained with the water-soluble rhodamine B, fat globules are devoid of any significant fluorescing material at the wavelength measured, and will appear black. Air pockets will also be devoid of fluorescent material and will also appear black, or perhaps gray if sufficient laser light is emitted from the fluorescent aqueous-protein

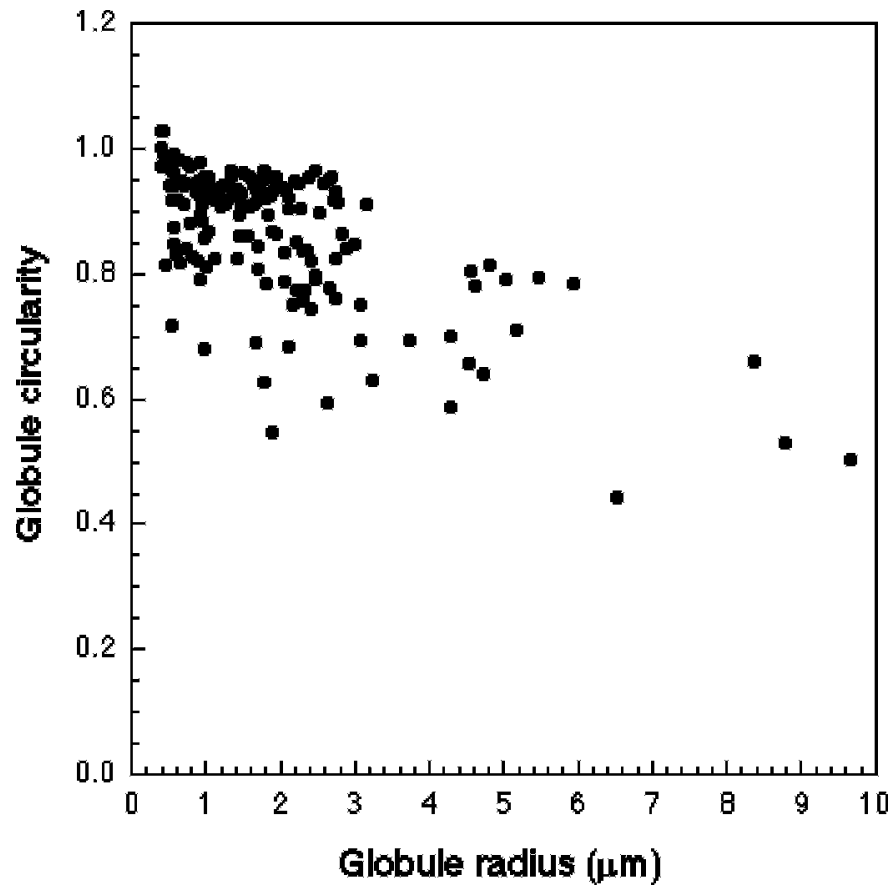

Figure 1. Fat globule circularity as a function of radius for cheese containing globules coated with $\alpha_{\mathrm{s} 2^{2}} \mathrm{CN}$ after $35 \mathrm{~d}$ of maturation. Circularity defined as $2 \pi(\mathrm{A} / \pi)^{0.5} / \mathrm{L}$ where $\mathrm{A}$ is the measured area of the globule and $\mathrm{L}$ is the perimeter length. phase at the bottom edge of the air pocket. Pockets of gray areas are sometimes evident in the images of freshly made Cheddar cheese, but the nature of these areas is not known. Air trapped between the cover slip and the top layer of the cheese sample appears to be of a similar intensity of gray to that of the observed pockets of unknown origin in unripened cheese. Confocal images of Gouda cheese stained with both a lipid soluble

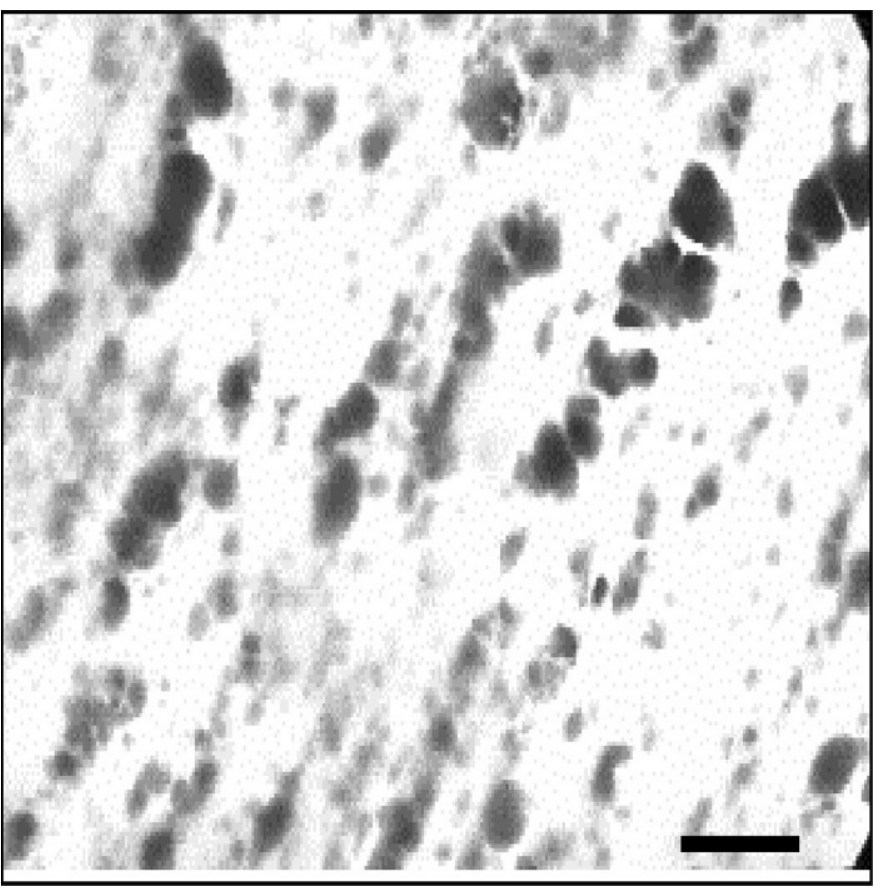

Figure 2. Control Cheddar cheese containing native fat globules after $70 \mathrm{~d}$ maturation at $8^{\circ} \mathrm{C}$. Scale bar $=20 \mu \mathrm{m}$. 


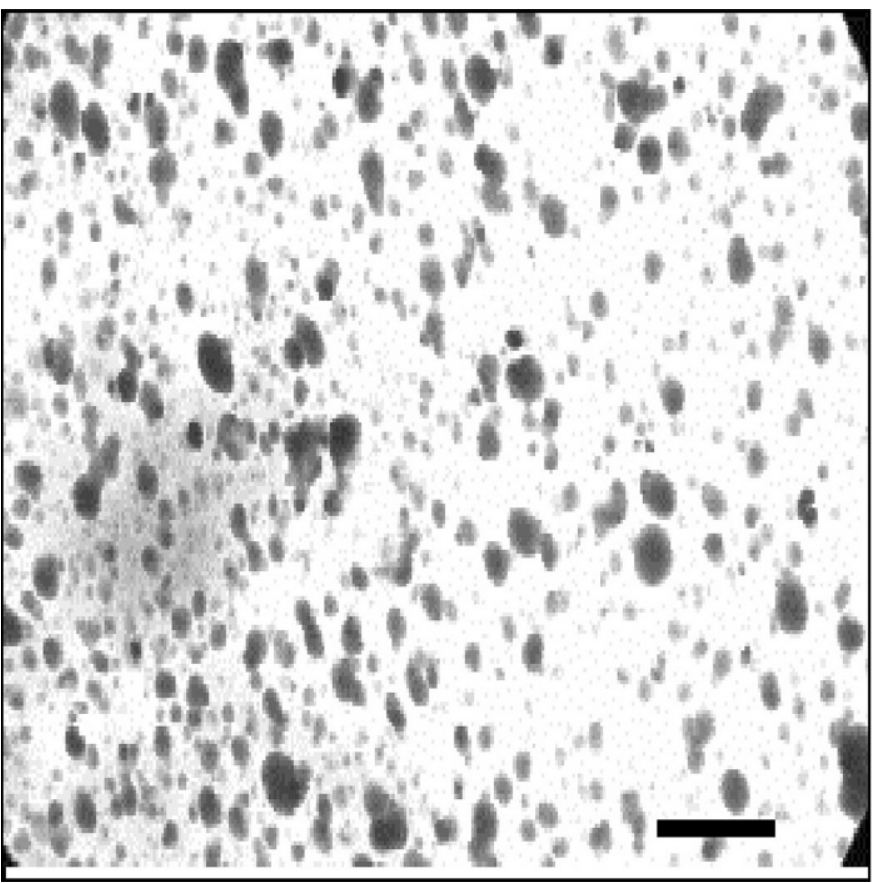

Figure 3. Cheddar cheese containing fat globules coated with $\alpha$ LA after $70 \mathrm{~d}$ maturation at $8^{\circ} \mathrm{C}$. Scale bar $=20 \mu \mathrm{m}$.

dye (Nile Red) or a water soluble dye (fluorescein isothiocyanate) and observed under split-screen dual-

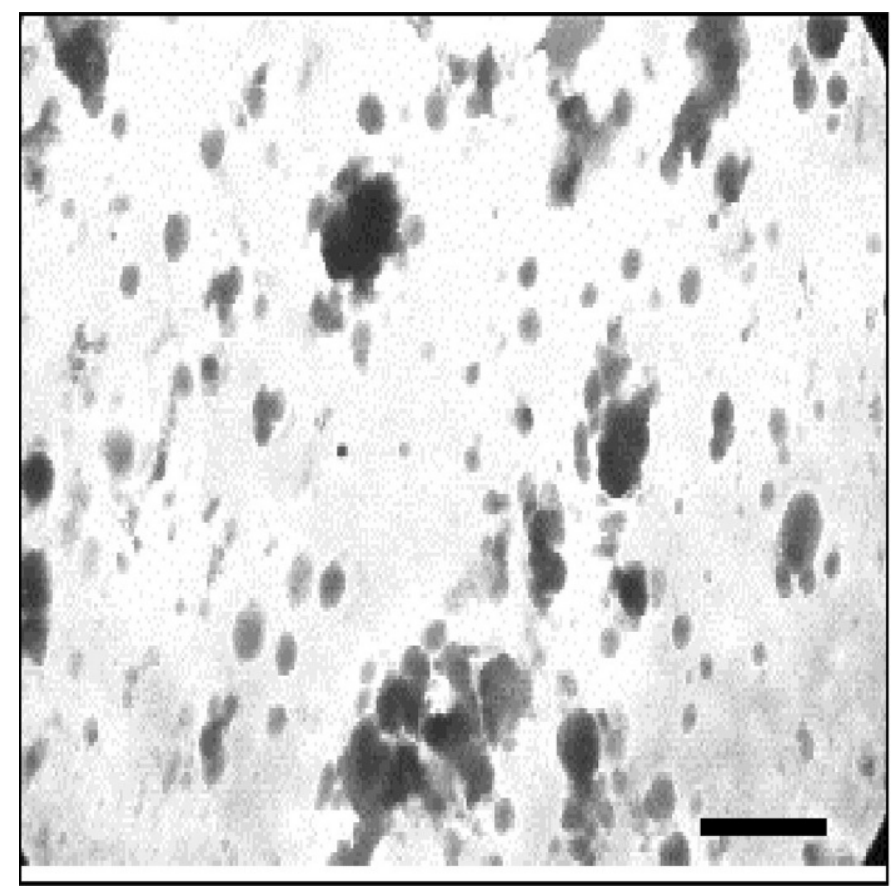

Figure 4. Cheddar cheese containing fat globules coated with $\alpha_{\mathrm{s}^{-}}$ $\mathrm{CN}$ after $70 \mathrm{~d}$ maturation at $8^{\circ} \mathrm{C}$. Scale bar $=20 \mu \mathrm{m}$.

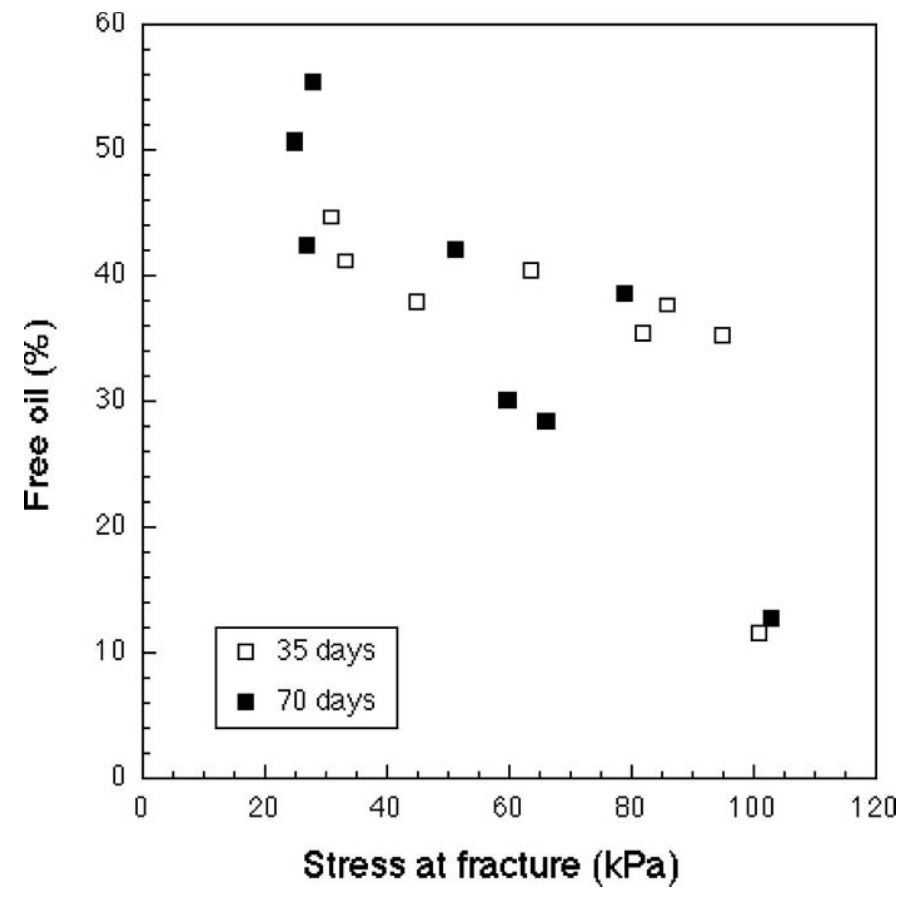

Figure 5. Free oil as a function of stress at fracture in cheese under uniaxial compression for different fat globule membrane coatings after $35(\square)$ and $70 \mathrm{~d}(\mathbf{\square})$ maturation $(\mathrm{n}=10)$. Free oil expressed as a percentage of total fat in cheese $(n=3), r=0.62$.

beam conditions show that the fluorescing fat globules containing Nile Red correspond very well with the areas that do not fluoresce in the fluorescein isothiocyanate image (Blonk and van Aalst, 1993), indicating that at least in Gouda cheese, air pockets are not common. The same conclusion can be drawn from the dual-beam experiment conducted in this study with Cheddar cheese.

The stiffness of fat globules can be represented by the expression

$$
\mathrm{G}=\frac{2 \mathrm{~T}}{\mathrm{R}}
$$

where $\mathrm{G}$ is the elastic modulus of deformability (representing "stiffness"), $R$ is the radius of the globule, and (T) is the surface tension (Walstra and Oortwijn, 1982). For natural milk fat globules, $\mathrm{T}$ is in the range 1 to 2 $\mathrm{mN} . \mathrm{m}^{-1}$ and radius is 1 to $10 \mu \mathrm{m}$. This yields a globule stiffness of 0.2 to $4 \mathrm{kPa}$. The stiffness of the protein matrix in cheese is 30 to $50 \mathrm{kPa}$ (Luyten, 1988), which is greater than the fat globule stiffness. After homogenizing milk, in this present study, and partially coating the globules with milk proteins, $\mathrm{T}$ is in the range 10 to $30 \mathrm{mN} \cdot \mathrm{m}^{-1}$ and radius is 2 to $4 \mu \mathrm{m}$. This yields a globule stiffness of 10 to $60 \mathrm{kPa}$, which is comparable to the 
Table 2. Rheological properties of cheese under uniaxial compression after 35 and $70 \mathrm{~d}$ maturation at $8^{\circ} \mathrm{C}$ $(\mathrm{n}=10)$.

\begin{tabular}{|c|c|c|c|c|c|c|c|c|}
\hline \multirow{3}{*}{$\begin{array}{l}\text { Coating } \\
\text { material }\end{array}$} & \multicolumn{4}{|c|}{$\mathrm{SR}^{1}$} & \multicolumn{4}{|c|}{$\tau_{\text {frac }}{ }^{2}(\mathrm{~Pa})$} \\
\hline & \multicolumn{2}{|c|}{$35 \mathrm{~d}$} & \multicolumn{2}{|c|}{$70 \mathrm{~d}$} & \multicolumn{2}{|c|}{$35 \mathrm{~d}$} & \multicolumn{2}{|c|}{$70 \mathrm{~d}$} \\
\hline & Mean & $\mathrm{SD}$ & Mean & SD & Mean & $\mathrm{SD}$ & Mean & $\mathrm{SD}$ \\
\hline$\alpha$-LA & 0.797 & 0.010 & 0.796 & 0.008 & 103 & 5 & 61.2 & 1.7 \\
\hline$\beta$-LG & 0.783 & 0.005 & 0.784 & 0.011 & 80 & 4 & 57.9 & 2.7 \\
\hline$\alpha_{\mathrm{s} 1}-\mathrm{CN}$ & 0.787 & 0.007 & 0.798 & 0.011 & 104 & 6 & 85 & 4 \\
\hline$\alpha_{\mathrm{s} 2}-\mathrm{CN}$ & 0.72 & 0.03 & 0.68 & 0.06 & 28 & 7 & 7.4 & 1.5 \\
\hline$\beta-\mathrm{CN}$ & 0.775 & 0.006 & 0.768 & 0.008 & 74 & 6 & 67 & 5 \\
\hline$\kappa-\mathrm{CN}$ & 0.788 & 0.006 & 0.787 & 0.009 & 76 & 4 & 51.3 & 3.3 \\
\hline Control 1 & 0.773 & 0.016 & 0.776 & 0.016 & 39.5 & 2.2 & 35.7 & 2.7 \\
\hline Control 2 & 0.802 & 0.022 & 0.770 & 0.011 & 40 & 7 & 43.7 & 1.6 \\
\hline
\end{tabular}

${ }^{1}$ Springiness ratio.

${ }^{2}$ Strain at fracture.

protein matrix stiffness. Larger globules coated with emulsifiers that do not reduce the surface tension as much as emulsifiers present on the natural milk fat globule will thus be more easily deformed in the cheese protein matrix. Small, native (and unhomogenized) fat globules will not be deformed as readily. The extreme case of a deformable globule is one that is large and has no emulsifying coat present (a pool of fat), and where no reduction in surface tension occurs. This type

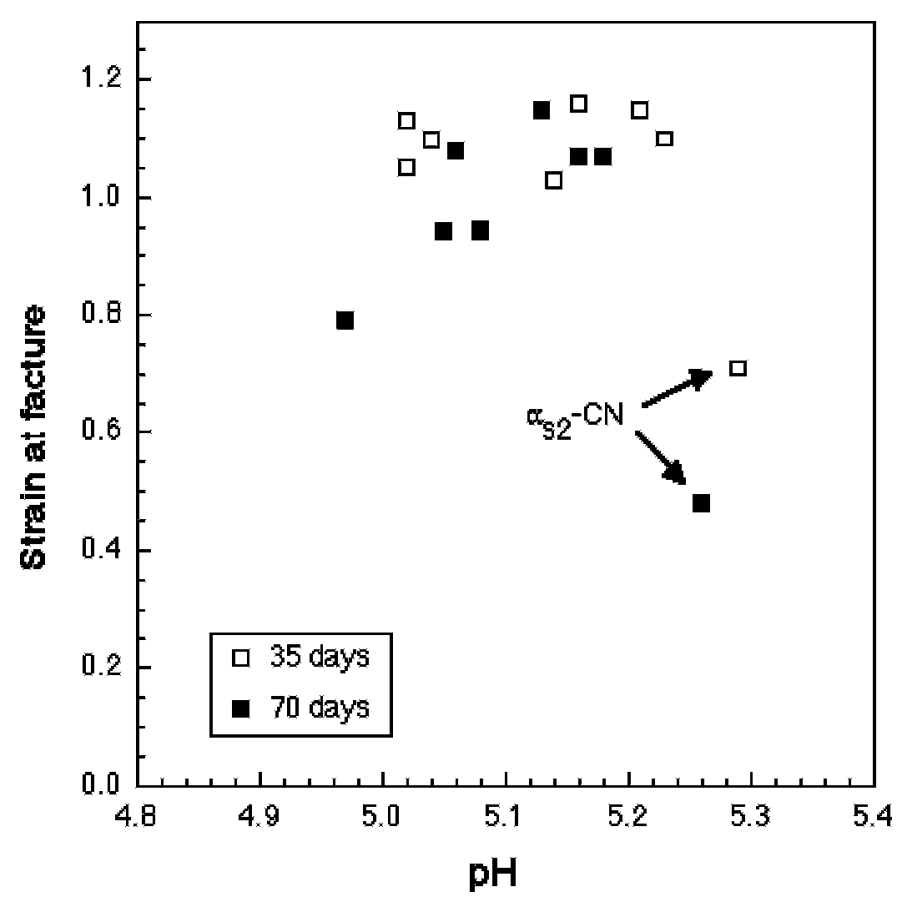

Figure 6. Strain at the point of fracture of cheese under uniaxial compression $(\mathrm{n}=10)$ at different $\mathrm{pH}$ values $(\mathrm{n}=3)$ after $35 \mathrm{~d}(\square)$ and $70 \mathrm{~d}(\square)$ maturation. Cheese containing fat globules coated with $\alpha_{\mathrm{s} 2^{-}}$ $\mathrm{CN}$ are identified with arrows, $\mathrm{r}=0.74$ (not including the two $\alpha_{\mathrm{s}^{-}}$ CN data points). of fat is evidently more common in cheeses containing native fat globules or fat globules originally coated with $\alpha \mathrm{s} 2$-CN during emulsion preparation. Clusters of emulsified globules were also evident in these two cheese types.

\section{Free Oil and Cheese Structure}

What actually constitutes free oil in cheese is open to debate. The technique used in this study to quantify

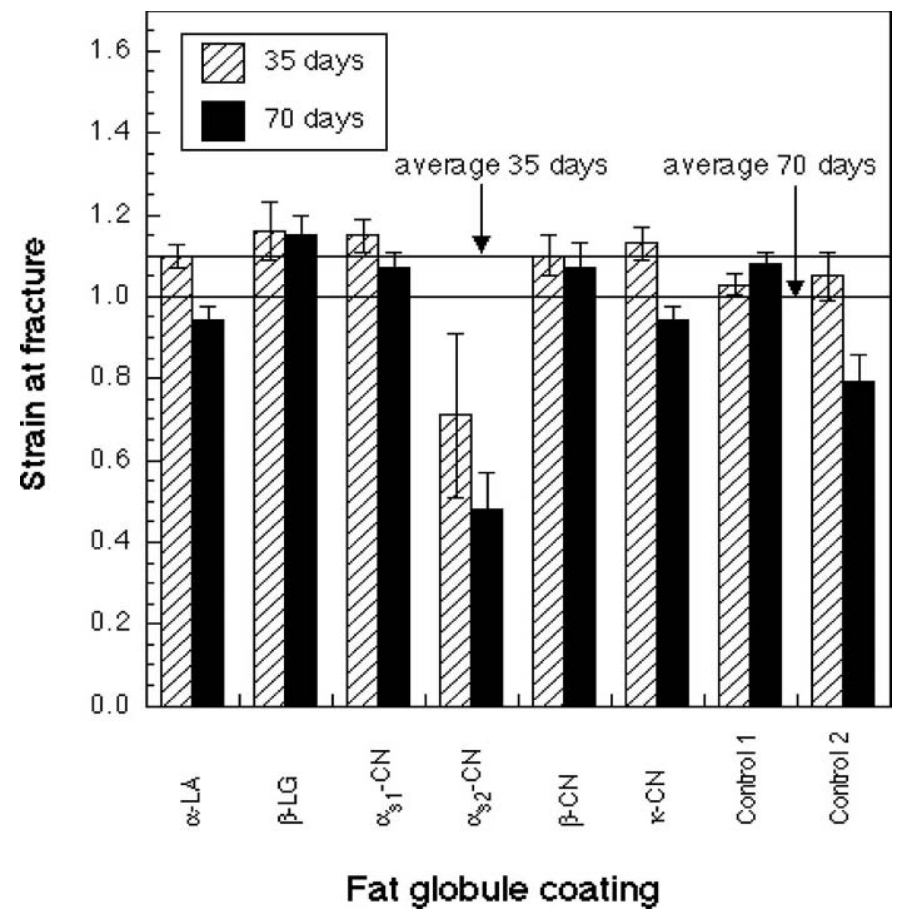

Figure 7. Strain at the point of fracture of cheese under uniaxial compression $(\mathrm{n}=10)$ for different fat globule membrane coatings after 35 and $70 \mathrm{~d}$ maturation. Control cheeses contain native fat globules. Averages are given for strain after 35 and $70 \mathrm{~d}$, excluding the data for $\alpha_{\mathrm{s} 2^{-}} \mathrm{CN}$. Error bars are $\pm \mathrm{SD}$. 
free oil involves immersing cheese in boiling water for a fixed amount of time and measuring the amount of oil that is released from the cheese after centrifugation. The oil that is released may originate from some of the larger fat globules in cheese, or perhaps from pools of fat that are not stabilized as emulsion droplets. The extent of proteolysis of both the cheese casein matrix and the adsorbed proteins on the interface, as well as the degree of interaction between emulsified fat membrane and the casein matrix, are perhaps the important parameters that will affect the formation of free oil.

As cheese curd $\mathrm{pH}$ decreases towards 5.4 during manufacture, the ionic species covalently bound to the casein strands become protonated allowing greater hydrophobic interaction between protein molecules. This will tend to produce a curd that is firmer and more elastic. Decreases in $\mathrm{pH}$ below 5.2 will result in the dissociation of the calcium phosphate bridges between casein molecules, resulting in a curd that becomes more brittle with a smaller strain at fracture (for example, crumble Cheshire cheese which has a $\mathrm{pH}$ of 4.8). This is evident from the data in Figure 6. These two effects are in competition, yielding a curd with maximum elasticity at $\mathrm{pH} 5.2$ to 5.4. Cheese with lower stress at the point of fracture also yielded a larger amount of free oil (Figure 5).

No significant correlation was found between free oil and fat globule circularity. A contrary result would be expected if fat with a greater propensity to undergo "oiling-off" are the large irregularly shaped globules in cheese that exist within voids in the protein matrix.

\section{Interactions Between the Fat Globule Surface and Casein}

Cheese containing fat globules coated with $\alpha_{\mathrm{s} 2}$-CN had the weakest structure, as shown by the low stress at fracture (Table 2) and strain at fracture (Figures 6 and 7). The $\alpha_{\mathrm{s} 2}$-CN molecule contains the greatest number of phosphate groups of the caseins, which will most likely be on the aqueous side of the interface when adsorbed onto the fat globule surface. If any micellar calcium phosphate bridging occurs between the $\alpha_{\mathrm{s} 2}-\mathrm{CN}$ on the interface and the surrounding casein matrix, the expected reinforcement of the cheese structure did not occur. Most of the calcium phosphate would be dissociated at the $\mathrm{pH}$ of cheese (less than 5.3), so calcium phosphate bridging may not occur to any significant degree.

Interaction between the $\alpha_{\mathrm{s} 2}$-CN-coated fat globule surface and the casein matrix through hydrophobic interaction would not be expected to be significant as the fat globule surface will be hydrophilic, with the hydrophobic portions of the adsorbed protein buried within the fat globule. This protein is the most highly charged and hydrophilic of the proteins used in this study, so would be expected to result in the least amount of hydrophobic interaction.

The lower strain at fracture for cheese containing globules coated with $\alpha_{\mathrm{s} 2}$-CN may be explained by a lesser degree of hydrophobic interaction between the globule surface and the surrounding casein matrix, resulting in a less cohesive and more brittle cheese. Renneted recombined milk containing fat globules coated with $\alpha_{\mathrm{s} 2}-\mathrm{CN}$ has a faster rate of primary coagulation, a slower rate of secondary coagulation, and a weaker gel structure compared to milk gels containing globules coated with other milk proteins or non-milk surfactants (Everett and Olson, 2000). The amphipathic and phosphorylated $\alpha_{\mathrm{s} 2}-\mathrm{CN}$, when adsorbed onto the surface of a milk fat globule, appears to interfere with the development of a strong gel structure in both renneted milk and cheese. Renneted milk containing fat globules coated with more uniformly hydrophobic proteins provides for a faster rate of secondary coagulation and a stronger gel structure (Everett and Olson, 2000), indicating that hydrophobic interactions are important for development of a strong protein network.

\section{CONCLUSIONS}

Confocal microscopy revealed the presence of two states of fat in cheese, small globules that are probably emulsified, and larger, more irregularly shaped globules believed to exist as either pools of fat within voids in the protein matrix or clusters of emulsified globules. This latter fat structure was more evident in cheese containing globules coated with the amphipathic and phosphorylated $\alpha_{\mathrm{s} 2}$-CN. No correlation was observed between free oil and fat globule circularity, although this would be expected if the less circular (and larger) pools of fat had a greater propensity to leak oil into the surrounding matrix. Fat globules coated with $\alpha_{\mathrm{s} 2}-\mathrm{CN}$ resulted in a weaker cheese structure. Hydrophobic fat globule membrane surfaces appear to be necessary for the development of a firm and less brittle cheese structure. Amphipathic and phosphorylated proteins at the globule interface, as exemplified by $\alpha_{\mathrm{s} 2}-\mathrm{CN}$, prevent the development of a strong protein structure in the maturing cheese.

\section{REFERENCES}

Ak, M. M., and S. Gunasekaran. 1992. Stress-strain curve analysis of Cheddar cheese under uniaxial compression. J. Food Sci. 57:1078-1081.

Andrews, A. T. 1983. Proteinases in normal bovine milk and their action on caseins. J. Dairy Res. 50:45-55.

Blonk, J. C. G., and H. van Aalst. 1993. Confocal scanning light microscopy in food research. Food Res. Int. 26:297-311. 
Brakenhoff, G. J., H. T. M. van der Voort, E. A. van Spronsen, and N. Nanninga. 1988. 3-dimensional imaging of biological structures by high resolution confocal scanning laser microscopy. Scanning Microscopy. 2:33-40.

Dickinson, E., S. E. Rolfe, and D. G. Dalgleish. 1990. Surface shear viscometry as a probe of protein-protein interactions in mixed milk protein films adsorbed at the oil-water interface. Int. J. Biol. Macromolecules. 12:189-194.

Emmons, D. B., M. Kaláb, E. Larmond, and R. J. Lowrie. 1980. Milk gel structure. X. Texture and microstructure in cheddar cheese made from whole milk and from homogenized low-fat milk. J. Texture Stud. 11:15-34.

Everett, D. W., and N. F. Olson. 2000. Dynamic rheology of renneted milk gels containing fat globules coated with different surfactants. J. Dairy Sci. 83:1203-1209.

Inoue, S. 1995. Foundations of confocal scanned imaging in light microscopy. Pages 1-14 in Handbook of Biological Confocal Microscopy. J. B. Pawley, ed. Plenum Press, New York, NY.

Johnson, M. E., and N. F. Olson. 1985. A comparison of available methods for determining salt levels in cheese. J. Dairy Sci. 68:1020-1024

Kaláb, M., and D. B. Emmons. 1978. Milk gel structure. IX. Microstructure of cheddared curd. Milchwissenschaft. 33:670-673.

Kimber, A. M., B. E. Brooker, D. G. Hobbs, and J. H. Prentice. 1974. Electron microscope studies of the development of structure in Cheddar cheese. J. Dairy Res. 41:389-396.

Kindstedt, P. S., and J. K. Rippe. 1990. Rapid quantitative test for free oil (oiling off) in melted Mozzarella cheese. J. Dairy Sci. 73:867-873.
Korolczuk, J., and M. Mahaut. 1992. Effect of homogenization of milk on the consistency of UF fresh cheeses. Milchwissenschaft. 47:225-227.

Law, B. A., M. E. Sharpe, H. R. Chapman, and B. Reiter. 1973. Relationship of milk fat globule membrane material to flavor development in Cheddar cheese. J. Dairy Sci. 56:716-723.

Lee, S. K., H. Klostermeyer, K. Schrader, and W. Buchheim. 1996. Rheological properties and microstructure of model processed cheese containing low molecular weight emulsifiers. Nahrung. 40:189-194.

Luyten, H. 1988. The rheological and fracture properties of Gouda cheese. Ph.D. Diss., Landbouwuniversiteit, Wageningen, The Netherlands.

Peleg, M. 1984. A note on the various strain measures at large compressive deformations. J. Texture Stud. 15:317-326.

Richardson, G. H., ed. 1985. Standard Methods for the Examination of Dairy Products. 15th ed. Am. Publ. Health Assoc., Inc., Washington, DC.

Shalabi, S. I., and P. F. Fox. 1987. Electrophoretic analysis of cheese: Comparison of methods. Irish J. Food Sci. Technol. 11:135-151.

van Vliet, T., and A. Dentener-Kikkert. 1982. Influence of the composition of the milk fat globule membrane on the rheological properties of acid milk gels. Neth. Milk Dairy J. 36:261-265.

Walstra, P., and H. Oortwijn. 1982. The membranes of recombined fat globules. III. Mode of formation. Neth. Milk Dairy J. 36:103-113.

Yiu, S. H. 1985. A fluorescence microscopic study of cheese. Food Microstruct. 4:99-106. 